\title{
INTER-UNION COMMISSION
}

\author{
$\mathrm{ON}$ \\ SOLAR AND TERRESTRIAL RELATIONSHIPS \\ INAUGURATION, CONSTITUTION AND HISTORY \\ INAUGURATION
}

The Commission held its inaugural meeting on 14 August 196I, prior to the Eleventh General Assembly of the International Astronomical Union. Professor C. W. Allen was elected to the Chair.

MEMBERSHIP

The initial membership of the Commission (subject to the acceptance of the nominees) was announced as follows:

IAU

(Astronomy)

C. W. Allen (U.K.)

J. F. Denisse (France)

R. Giovanelli (Australia)

E. R. Mustel (U.S.S.R.)
IUGG

(Geodesy and Geophysics)

J. Bartels (Germany)

B. Haurwitz (U.S.A.)

F. Link (Czechoslovakia)

M. Nicolet (Belgium)
URSI

(Scientific Radio)

G. M. Allcock (New Zealand)

D. K. Bailey (U.S.A.)

R. Coutrez (Belgium)

A. H. Shapley (U.S.A.)

Allen, Denisse, Giovanelli, Mustel, Nicolet, Bailey and Shapley were present. In response to an open invitation there was also an audience of about fifty, drawn mainly from IAU membership. Some of these contributed to discussions.

The following Officers were elected:
as President
C. W. Allen
as Secretary
D. K. Bailey

The meeting also appointed E. N. Parker as a Corresponding Member.

The President made reference to the main points of the Constitution which had been drafted by the General Secretary of the IAU. The Constitution adopted by the Commission reads as follows:

\section{CONSTITUTION OF THE INTER-UNION COMMISSION ON SOLAR AND \\ TERRESTRIAL RELATIONSHIPS}

\section{Constitution}

I. The International Astronomical Union (IAU), in co-operation with the International Union of Geodesy and Geophysics (IUGG) and the International Scientific Radio Union (URSI), establishes an Inter-Union Commission on 'Solar and Terrestrial Relationships' ('Relations entre les Phénomènes Solaires et Terrestres') as a successor to the former Joint Commission of the International Council of Scientific Unions.

2. The Commission operates under the general rules governing Commissions of the IAU and reports to the IAU, which undertakes to consult the other Unions in all appropriate matters. 


\section{Composition}

3. The Commission consists of twelve members, four of whom are appointed by each of the three co-operating Unions. At least one of the four members appointed by each Union is to be replaced, at intervals of not more than three years, by a new member who has not served as a member of the Commission during the previous six years.

4. The Commission appoints its President, and other Officers, from among its members. Officers may not serve in the same capacity for more than six years.

5. The Commission may appoint Corresponding Members, up to six in number, to serve as advisers.

\section{Meetings and Publications}

6. The Commission will meet at least every three years.

7. The Commission is encouraged to organize symposia, either in conjunction with its meetings or at other times.

8. The Commission is authorized to arrange for the publication of the proceedings of meetings and symposia.

9. In accord with Article 2, the arrangements for meetings, and summary reports of those meetings, are to be reported to the General Secretary of the IAU. Proposals for symposia, and for publications, are to be submitted to the IAU for approval in consultation with the other Unions.

\section{Finance}

10. The IAU, through arrangements with the other Unions and other agencies, assumes responsibility for financial support of the Commission and its activities.

II. The Commission will submit requests for financial support, estimates of costs of symposia and publications, and accounts of income and expenditure to the IAU in accord with usual procedures.

\section{Explanatory notes}

In addition to supplying the draft Constitution the General Secretary of the IAU provided a useful Addendum explaining how the Commission might be expected to operate in matters not formally treated in the Constitution. Important points from this addendum are:

(a) The IAU will attempt to arrange that the membership from the three Unions should be in accord with adequate scientific and regional representation.

(b) The President and Secretary should not be members appointed by the same Union, nor nationals of the same country.

(c) The General Secretary of the IAU should be fully informed of all activities. Reports will be sent to other Unions.

(d) Commission meetings will generally be held in close association with a General Assembly of the IAU or one of the other Unions.

(e) Publication of the proceedings of meetings or of symposia will require approval by the three Unions.

(f) Limited funds will be available for secretarial expenses. The travelling expenses (in part or in total) of the President and Secretary in attending meetings will be reimbursed, and a grant will be available to assist the other members.

(g) The IAU will endeavour to obtain funds to meet expenses incurred by the Commission from sources outside its own proper income; to the extent to which it is unable to do this it will call on the other Unions for contributions. 


\section{RECENT HISTORY}

The President then gave a brief account of the activities of the last three years which had led to the formation of the new Inter-Union Commission on Solar and Terrestrial Relationships (IUCSTR) in replacement of the old Joint (or Mixed) Commission on Solar and Terrestrial Relationships (JCS'TR). At the last meeting of the JCS'TR (Geophys. $\mathcal{F . ~ 2 , ~ 3 6 9 , ~ 1 9 5 9 ) ~ t h e ~ r e t i r i n g ~}$ President, Dr L. d'Azambuja explained that the future of that Commission was hanging in the balance. Various proposals were made for the continuance of the work. However later in I958 the JCSTR was dissolved by the International Council of Scientific Unions (ICSU). At the same time ICSU attempted to set up a Committee of three to advise on future action. The formation of this Committee was attended with some unavoidable delays, and the final composition was

Professor C. W. Allen, London (IAU) (Convenor)

Dr A. H. Shapley, Colorado (URSI)

Professor J. T. Wilson, Toronto (IUGG)

The recommendations of this Committee, reported in 1960 , were:

r. That the JCSTR be reconstituted as an Inter-Union Commission.

2. That the new Commission be established by the IAU, the IUGG, and the URSI, with IAU as parent Union.

3. That the new Commission consist of 12 members.

4. That the constitution be based on the Draft Constitution outlined by the General Secretary of the IAU.

5. That the Executives of each of the Unions-IAU, URSI and IUGG-be invited to nominate four initial members of the proposed new Commission.

6. That a meeting be held in London in September 1960 (during the General Assembly of URSI) when the present position could be explained to Members and Councillors of the old JCSTR, and some future activities planned.

The report was accepted by the ICSU and future action based on it.

The recommended meeting was held in Lordon in September 1960 and was attended by C. W. Allen, A. H. Shapley, G. Righini, M. Waldmeier, E. Vassy, J. Rösch, M. Nicolet, and D. K. Bailey. The main purpose of the meeting was to act as some liaison between the old and the new Commissions and make any proposals that might be helpful to the incoming Commission. It was suggested that the main part of the Berkeley Meeting of the Commission might take the form of a Symposium on 'Solar Terrestrial Relations-insight resulting from the International Geophysical Year'.

It had been intended that the present meeting should follow this recommendation as far as possible, and to this end a number of speakers were to speak on items concerned with this general topic. It had to be remembered however that the meeting in progress was formally a Commission Meeting-not a symposium. Business of the newly formed Commission should take first priority. The meeting proceeded to a discussion on the future of the IUCSTR. 
THE FUTURE OF THE IUCSTR

Scope of 'Solar and Terrestrial Relationships'. It was suggested that an important function of the IUCSTR should be to fill the gap between solar observations (Commission IO) and terrestrial observations (IUGG). The main subject matter of the Commission concerns (a) disturbances in optical photon emission from the Sun, and $(b)$ corpuscular disturbances from the Sun; but the Commission must be ready to consider effects that do not fall into these categories. Measurements of interplanetary space are particularly the concern of COSPAR and a widespread overlap must be avoided. It was agreed we should concentrate on observations of the Sun connected with corresponding measurements on the Earth.

Review report. The major activity of the old JCSTR has been the triennial publication of its report Relations entre les phénomènes solaires et terrestres. It is hoped that in the new IUCSTR it will be possible to produce a report that is somewhat similar but with a wider distribution. This should be instead of the usual President's report that is issued by IAU Commissions. In addition to reports on progress in the last few years it is desirable to include some reports defining, as far as possible, independent present-day views on long-standing controversial subjects. The possibility of publishing flare-event lists was also discussed.

Symposia and meetings. The IUCSTR is encouraged to organize symposia, but all proposals require the approval of the IAU, in consultations with the IUGG and URSI. It is to be remembered that such symposia are to some extent in competition with those of other Unions, Commissions, learned societies, etc. The meeting hoped that it would be possible to hold some symposia in connection with IUGG or URSI meetings. It was recommended that a business meeting of the IUCSTR should be associated with each General Assembly of the IAU and that on these occasions there should also be a scientific session at which short contributions could be offered. Symposia might be held at other times and dominated by invited papers.

Quarterly Bulletin of Solar Activity. Dr M. Waldmeier said that it would be helpful if the IUCSTR could act as an advisory committee for the Quarterly Bulletin. The Commission expressed its willingness to act in this capacity, and suggested that the request for any such action should come from the IAU through Commission ro. The President of Commission ro (Dr A. B. Severny), who was present, promised to consider this matter in his Commission meeting. [It was later agreed by the Executive Committee of the IAU, after consultation with Commission I0, that the IUCSTR be invited to act as an advisory committee.]

International Quiet Sun Year. Consideration was given to the part of the IUCSTR in the coming IQSY. It was decided that the IUCSTR should send a reporter to meetings of the IQSY when possible, and the Secretary (D. K. Bailey) was named as reporter to the next CIG (Comité Internationale de Géophysique) meeting in January or February 1962.

Operation. The President and Secretary are expected to act as convenors for the operations of the IUCSTR. The role of the Commission will be somewhat that of a consultative council. It may be necessary to form sub-committees. It was felt that in addition to the Commission Members and Corresponding Members, it was necessary to set up a Roster of Active Workers, which should be representative of all workers that are active in this field. It might be expected that the list would contain more than Ioo names and be open to anyone willing to take part in the wider activities of the IUCSTR. The purpose of this roster would be for $(a)$ seeking advice, (b) distributing notices of activities, and (c) requesting review articles. 